\title{
ANALISIS STRATEGI POSITIONING PRODUK BERDASARKAN PERSEPSI KONSUMEN PADA INDUSTRI BATIK DI JAWA TIMUR
}

\author{
Kristiningsih ${ }^{1}$ \\ Program Studi Manajemen, Universitas Wijaya Kusuma, Surabaya, Indonesia \\ kristiningsih@uwks.ac.id \\ Lestari ${ }^{2}$ \\ Program Studi Manajemen, Universitas Wijaya Kusuma, Surabaya, Indonesia \\ Lestari_10@yahoo.co.id \\ Wiwik Herawati ${ }^{3}$ \\ Program Studi Manajemen, Universitas Wijaya Kusuma, Surabaya, Indonesia \\ wiwikherawati@gmail.com
}

\begin{abstract}
Background - Competition in the Batik industry in Indonesia is quite sharp. Therefore it is necessary to apply the right marketing strategy in this industry. Whereas each batik industry that originates from the region has its own uniqueness that can attract the attention of consumers. Therefore, a positioning strategy for batik products is needed to be able to create more value in the minds of consumers compared to its competitors
\end{abstract}

Purpose - This research purposed to describe the position of competition (positioning) on batik industry in East Java based on the perceptions of local batik consumers.

Design / Methodology / Approach - The study took samples of batik consumers in 9 cities in East Java, namely Bangkalan, Sidoarjo, Lamongan, Tuban, Pasuruan, Tulungagung, Mojokerto, Ponorogo and Banyuwangi. The population was taken by using purposive sampling technique. Respondents were taken as many as 200 respondents from selected batik producing cities. The research was conducted on 9 kinds of attributes that distinguish the distinctive characteristics of batik between regions in East Java including the quality of the fabric used, the quality of the coloring of the fabrics used, the patterns or motifs, the various colors, prices, design innovation, popularity, value art and intrinsic meaning. To conduct the analysis, analysis techniques using multidimensional scaling were used.

Results and Discussion - The results showed a significant difference between the batik in each region which shows the characteristics of the area. The implication of this research was very useful for batik business in East Java to find out their competitive position among this industry in East Java, so that they can determine the right competition strategy according to the advantages or characteristics of each region. Conclusion - There are differences in perceptions of the quality attributes of the fabric material, the quality attributes of fabric coloring, batik patterns or motifs, various colors, prices, design innovation, popularity, artistic value and intrinsic meaning of batik batik in East Java which is the object of this research.

Research implication - The research contributions are presented in the form of theoretical contributions and practical contributions. The theoretical contribution made is that this study supports previous research, that marketers can find out the competitive position in the industry through the perceived attributes of consumers. The implication of this research is very useful for marketers to find out who their close competitors are so that marketers can apply the right strategy to deal with competitors. Batik entrepreneurs or craftsmen should make products with high artistic value that characterize the Indonesian culture.

Research limitations - The limitation of this study lies in the sample selection, because consumers only know the product attributes that they know, in the next research, consumer selection should preferably be on consumers who know all the characteristics of the businesses being compared. Further research can also examine the segmentation, targeting and positioning policies of batik products in marketing their products in the community. 
Keywords: Positioning of, Batik, Consumer, Perceived, Multidimensional, Scalling

\begin{abstract}
ABSTRAK
Latar Belakang - Persaingan dalam industry Batik di Indonesia cukup tajam. Oleh karena itu perlu diterapkan strategi pemasaran yang tepat pada industry ini. Bahwa setiap industry batik yang berasal dari daerah memiliki kekhasan tersendiri yang dapat menarik perhatian konsumen.Oleh karena itu strategi positioning produk batik diperukan untuk bisa menciptakan nilai lebih di benak konsumen dibanding pesaing pesaingnya.
\end{abstract}

Tujuan - Penelitian ini bermaksud untuk mendeskripsikan posisi persaingan (positioning) pada industry batik di Jawa Timur berdasarkan persepsi konsumen batik lokal.

Desain/ Metodologi/ Pendekatan - Penelitian mengambil sampel pada konsumen batik di 9 kota di Jawa Timur yaitu Bangkalan, Sidoarjo, Lamongan, Tuban, pasuruan, Tulungagung, Mojokerto, Ponorogo dan Banyuwangi. Populasi diambil dengan teknik purposive sampling. Responden diambil sebanyak 200 responden dari kota penghasil batik terpilih. Penelitian dilakukan pada 9 macam atribut yang membedakan ciri khas batik antar daerah di Jawa Timur meliputi Kualitas bahan kain yang digunakan, Kualitas Pewarnaan Kain Yang Digunakan, corak/motif, ragam warna, harga, inovasi desain, popularitas, nilai seni dan makna intrinsic. Untuk melakukan analisis digunakan tenik analisis dengan menggunakan multidimensional scalling.

Hasil dan Pembahasan - Hasil penelitian menunjukkan perbedaan yang signifikan antara batik di tiap tiap daerah yang menunjukkan ciri khas daerah tersebut. Implikasi dalam penelitian ini sangat berguna bagi pengelola usaha batik di Jawa Timur untuk mengetahui posisi bersaing mereka diantara usaha batik di Jawa Timur, sehingga bisa menentukan strategi peraingan yang tepat sesuai dengan keunggulan/ciri khas masing masing daerah.

Kesimpulan - Terdapat perbedaan persepsi atas atribut kualitas bahan kain, atribut kualitas pewarnaan kain, Corak atau motif batik, Ragam warna, Harga, Inovasi desain, Popularitas, Nilai seni dan Makna intrinsik batik batik di Jawa Timur yang menjadi obyek penelitian ini

Implikasi penelitian - Kontribusi penelitian ini disajikan dalam bentuk kontribusi teoritis dan konribusi praktis. Kontribusi teoritis yang dihasikan adalah bahwa penelitian ini mendukung penelitian sebelumnya, bahwa pemasar bisa mengetahui posisi persaingan dalam industri melalui atribut yang dipersepsikan konsumen. Implkasi penelitian ini sangat berguna bagi pemasar untuk mengetahui siapa pesaing terdekatnya sehingga pemasar dapat menerapkan strategi yang tepat untuk menghadapi pesaing tersebut. Pengusaha atau pengajin Batik sebaiknya membuat produk dengan nilai seni yang tinggi yang mencirikan budaya bangsa indonesia.

Batasan penelitian - Keterbatasan penelitian ini terletak pada pemilihan sampel, karena konsumen mengetahui atribut produk yang diketahuinya saja, pada penelitian selanjutnya pemilihan konsumen sebaiknya pada konsumen yang mengetahui semua karakteristik dari usaha yang dibandingkannya. Penelitan selanjutnya juga dapat meneliti mengenai kebijakan segmentasi, targeting dan positioning produk batik dalam memasarkan produknya di masyarakat.

Kata Kunci: Positioning, Batik, Perserpsi, Konsumen, Multidimensional, Scalling

\section{PENDAHULUAN}

Industri Kecil Menengah (IKM) di Indonesia umumnya memproduksi barang barang konsumsi pada berbagai macam kategori produk. Di Indonesia, produk yang dihasilkan IKM adalah lebih banyak berupa barang barang konsumsi seperti produk pakaian, kain, adan perlengkapan rumah tangga yang banyak ragamnya. Industri industri tersebut masih bertahan walaupun menghadapi persaingan tajam di dalam dan luar negeri, sehingga diperlukan strategi yang tepat untuk bisa bertahan dalam persaingan tersebut. Salah satu cara adalah dengan membangun keunikan produk yang membedakannya satu dengan yang lain, 
sehingga dapat diminati oleh pembeli dalam pasar tertentu.

Pada umumnya kesulitan terbesar yang sering dihadapi industri kecil menengah adalah berkaitan dengan perluasan pemasaran produk mereka. Jika IKM tidak melakukan perbaikan pada unsur pemasaran secara berkesinambungan, maka mereka akan menemui kesulitan dalam menghadapi persaingan baik dari produk domestik maupun produk impor. Industri batik adalah sebuah industri yang sebagian besar pemiliknya adalah IKM (Ariem et al., 2010)

Batik di Indonesia khususnya di Jawa Timur memiliki corak/motif yang beraneka ragam yang menunjukkan kekhasan batik tersebut darimana berasal. Ada barbagai macam corak bila dicermati pada kain batik di Indonesia khususnya Jawa Timur. Saat ini secara garis besar terbagi ke dalam dua kategori, yaitu batik halus dan batik kasar. Untuk jenis produk batik halus menggunakan bahan sutera Alat dari Tenun Bukan Mesin (ATBM). Semua tergantung dari tingkat kesulitan dalam pengerjaannya serata pemilihan bahannya (Alhusain, 2015).

Persaingan dalam Industri batik di Indonesia sangat ketat. Hal ini mengharuskan para pemilik Usaha batik untuk menentukan strategi pemasaran yang tepat. Pertama adalah dengan menetapkan target pasar siapa yang akan dituju, sehinga dapat memuaskan kebutuhan konsumen tersebut dengan memberikan kualitas produk yang terbaik bagi konsumen. Para IKM batik menyadari bahwa sulit untuk melayani seluruh pelanggan dalam pasar batik, maka mereka akan memilih satu atau beberapa target pasar. Pasar sasaran (target pasar) adalah kelompok konsumen yang memiliki karakteristik sama yang dipilih perusahaan untuk dilayani. (Kotler dan Amstrong, 2008).

Perilaku konsumen bersifat labil, artinya mudah berubah sejalan dengan perubahan waktu, maka pengusaha batik harus bisa mengantisipasi perubahan tersebut. Setiap perusahaan akan berupaya untuk dapat menempatkan produk mereka di hati konsumennya, yang disebut sebagai positioning. Pelaku usaha batik seharusnya mengetahui bagaimana posisi persaingan mereka yang dapat secara langsung atau tidak langsung mempengaruhi daya tarik dari pasar mereka. Terdapat beberapa faktor yang dapat mempengaruhi posisi pasar, yaitu: (1) potensi pesaing baru, (2) persaingan antar segmen, (3) Keberadaan produk substitusi, (4) hambatan masuk dalam insudtri, (5) adanya barang pelengkap, dan kekuatan tawar menawar dari pemasok.

Apabila pelaku usaha batik sudah mementuka segmen pasar yang akan mereka layani, maka langkah berikutnya 
adalah memikirkan bagaimana memposisikan keunggulan yang dimiliki disbanding pesaingnya pada konsumen sasaran tersebut. Hal ini akan menjadikan usaha tersebut berbeda dibandingkan pesaingnya. (Swastha dan Irawan, 1990).

Penelitian mengenai strategi positioning produk batik pernah dilakukan oleh Johannes dan Erida (2018) mengenai strategi positioning batik di daerah Jambi. Analisis dilakukan dengan analisis faktor faktor yang dipersepsikan konsumen atas atribut batik. Penelitian ini tidak dapat mengetahui kedekatan posisi persaingan antar usaha dalam industry tersebut. Maka dalam penelitian ini dengan pendekatan analisis Multidimensional scalling diharapkan dapat menghasilkan peta persaingan antar UKM batik tersebut, hal ini menjadikan sebuah riset gap dalam penelitian ini.

Penelitian ini bertujuan untuk Menganalis strategi positioning berdasarkan persepsi konsumen produk Batik di Jawa Timur, sehingga akan memudahkan para IKM batik tersebut untuk bisa mengetahui posisi bersaing disbanding pesaing pesaingnya.

\section{TINJAUAN PUSTAKA}

\section{Strategi Pemasaran}

Strategi pemasaran telah banyak didefinisikan oleh para ahli pemasaran. Kotler dan Armstrong (2006) mendefiniskan strategi pemasaran sebagai sebuah cara pemasaran yang mengharapkan perusahaan dapat menciptakan nilai (value) yang baik serta relasi yang menguntungkan dengan konsumennya. Menurut Kotler (2008) langkah pertama dalam menentukan strategi pemasaran adalah menentukan Strategi STP (segmentasi, targeting, positioning). Dalam penelitian Zakaria et al., (2005) dinyatakan bahwa perusahaan dapat melakukan segmentasi berdasarkan persepsi konsumennya. Target pasar dapat dipilih berdasarkan segmentasi tersebut sehingga memudahkan perusahaan menentukan strategi memposisikan produknya di pikiran konsumen. Beberapa tahapan dalam menentukan STP adalah sebagai berikut (Kotler, 2007)

1. Menentukan Segmentasi pasar,dengan cara :

a. Identifikasi variabel segmentasi

b. Menentukan profil dari masing masing segmen pasar.

2. Tahap kedua adalah menetapkan pasar yang dituju

a. Melakukan evaluasi setiap segmen dengan melihat daya Tarik masing masing

b. Memilih segmen pasar yang dituju, bisa satu atau lebih

3. Memposisikan produk disbanding pesaing

a. Mengeksplorasi setiap positioning yang memungkinkan 
b. Memilih konsep positioning yang sesuai

\section{Segmentasi Pasar}

Rhenald Kasali dalam (Oentoro, 2012) menyatakan bahwa segmentasi merupakan proses mambagi bagi pasar yang bersifat heterogen/ beragam dalam kelompok yang lebih kecil yang mempunyai kemiripan dari sisi kebutuhan atau kesamaan karakter atau respon yang sama dalam menentukan keputusan pembeliannya.

Banyak perusahaan di industri dasar beralih ke produk khusus dalam upaya meningkatkan pertumbuhan dan keuntungan. Tetapi gerakan seperti itu seringkali membutuhkan keterampilan pemasaran yang tidak biasa, terutama dalam segmentasi dan pemosisian. Literatur pasar secara mengejutkan tidak memiliki contoh praktis dari teknik segmentasi dan penentuan posisi yang diterapkan pada pasar industri (Doyle, 1985)

Penetapan dasar segmentasi Kotler (2008) menyatakan bahwa terdapat 2 macam cara yang dapat dilakukan, yang pertama adalah berdasar karakteristik konsumen yang merupakan variabel utama dalam segmentasi, meliputi:

$\begin{array}{ccc}\text { 1. Segmentasi } & \text { Geografi, } & \text { adalah } \\ \text { segementasi } & \text { yang dilakukan }\end{array}$ berdasarkan faktor geografinya, seperti berdasarkan asal daerah atau tempat tinggal konsumen.
2. Segmentasi demografis adalah pengelompokan yang dilakukan atas dasar variabel pekerjaan, usia, jenis kelamin dan pendidikan konsumen.

3. Segmentasi psikografis adalah pengelompokan didasarkan pada karakteristik setiap konsumen, seperti motivasi, kepribadian, persepsi, interest, minat dan sikap.

Cara untuk melakukan segmentasi kedua adalah didasarkan respon konsumen yang terdiri dari Benefit segmentation yaitu pengelompokan yang di dasarkan kepada manfaat yang diinginkan konsumen dari suatu produk atau jasa, use occasion dan brand atau merek. Cara ini konsumen akan dikelompokkan berdasar respon mereka terhadap produk atau jasa, seperti ada konsumen yang mementingkan kualitas dan ada konsumen yang mementingkan harga yang murah.

\section{Targeting}

Adanya penetapan pasar sasaran atau targeting yang baik akan memudahkan perusahaan dalam mengalokasikan produk dan jasa kepada konsumen. Targeting adalah proses mengevaluasi daya tarik (attractiveness) setiap segmen pasar kemudian memilih satu atau beberapa segmen pasar untuk dimasuki (Kotler, 2008). Menurut Tjptono (2008) ketika perusahaan akan memilih target pasar, maka ada tiga factor yang harus diperhatikan: 
1. Ukuran atau perkembanagan pasar, perusahaan harus menentukan apakah suatu segmen potensial, memiliki karakteristik ukuran, dan pertumbuhan yang tepat.

2. Daya tarik dari segmen yang ada, dalam hal ini perusahaan menilai dampak profitabilitas jangka panjang, yang mempengaruhi industri secara keseluruhan maupun setiap segmen yang ada didalamnya

Moschis (1997) dalam penelitiannya menunjukkan bahwa populasi yang menua telah menarik perhatian para pemasar, tetapi banyak perusahaan masih tidak yakin apakah mereka harus melakukan pemasaran ke pasar yang sudah matang. Menyoroti beberapa masalah utama yang dihadapi pemasar dan membahas alasan penerapan strategi tertentu. Menyimpulkan bahwa, agar strategi pemasaran menjadi efektif, dengan mempertimbangkan heterogenitas pasar yang matang dan produk atau layanan tertentu yang dipasarkan. Menggunakan hasil studi terbaru untuk menggambarkan bagaimana strategi spesifik produk target tersebut dapat dikembangkan.

\section{Positioning}

Positioning adalah kegiatan penawaran perusahaan menganai citra perusahaan untuk berada pada posisi khusu di benak target pasar yang dituju, dibandingkan pesaingnya (Kotler and Keller, 2008).
Menurut Tjiptono (2008) ada tujuh macam cara yang dapat digunakan perusahaan untuk memposisikan penawarannya, meliputi:

1. Positioning berdasarkan ciri khas, manfaat atau atribut yang dimiliki (attribute positioning), yaitu dengan jalan mengasosiasikan suatu produk dengan manfaat bagi pelanggan.

2. positioning kesan yang diciptakan sebagai produk berkualitas tinggi lewat harga

3. Positioning berdasarkan siapa pemakai produk (user positioning) yaitu mengaitkan produk dengan kepribadian atau tipe pemakai

4. Positioning berdasarkan harga dan kualitas (price and quality positioning)

5. Positioning yang dilandasi dengan aspek penggunaan atau aplikasi (use application positioning), yaitu seperangkat nilai -nilai penggunaan yang digunakan sebagai unsur yang ditonjolkan dibandingkan pesaingnya.

6. Positioning berdasarkan kelas produk tertentu (product class positioning), misalnya permen kopiko yang diposisikan sebagai kopi dalam bentuk permen, bukan permen rasa kopi.

7. Positioning berkenaan dengan pesaing (competitor positioning) yaitu dikaitkan

8. dengan posisi persaingan terhadap pesaing utama. 
9. Positioning berdasarkan manfaat (benefit positioning) yaitu menghubungkan merk dengan salah satu karakteristik atau fitur produk yang diharapkan bisa dirasakan sebagai keunggulan yang diinginkan oleh konsumen

Penelitian mengenai positioning produk dilakukan pada beberapa obyek berbeda Putri et al., (2018) melakukan penelitian mengenai positioning produk Smartphone di Samarinda, untuk mengetahui peta posisi persaingan Smartphone berdasarkan atas atribut yang dipersepsikan konsumen. Penelitian lain juga dilakukan oleh Syahputra et al., (2014) yang meneliti tentang peta posis persaingan antar bisnis travel di kota Bandung berdasrkan atribut yang dipersepsikan konsumen.

\section{METODOLOGI PENELITIAN}

\section{Pendekatan Penelitian}

Jenis penelitian yang digunakan adalah penelitian deskriptif, merupakan penelitian yang dilakukan untuk mendeskripsikan/ mengetahui nilai variabel mandiri. Dalam penelitian ini yang dikur adalah variabel positioning produk batik di Jawa timur.

\section{Teknik Pengumpulan Data}

Pengumpulan data dalam penelitian ini menggunakan kuesioner yang disebarkan kepada para pelanggan batik di Jawa Timur khususnya pada batik di 9 kota di Jawa Timur yaitu Bangkalan, Sidoarjo, Lamongan, Tuban, pasuruan, Tulungagung, Mojokerto,
Ponorogo dan Banyuwangi. Kesembilan kota tersebut dipilih karena memiliki karekteristik/ ciri khas yang berbeda batik batik produksinya.

\section{Populasi dan Sampel}

Populasi dalam penelitian ini adalah semua konsumen batik yang berada pada sentra industri batik yang menjadi obyek penelitian Metode pengambilan sampel yang digunakan adalah Purposive sampling. yaitu teknik penentuan sampel berdasarkan pertimbangan-pertimbangan tertentu (Sugiyono, 2010). Dimana responden yang dijadikan sampel sesuai dengan kriteria yang ditentukan peneliti yaitu responden yang merupakan konsumen dari industri batik Jawa Timur, berusia 17 tahun ke atas dan mengetahui atribut batik. Sampel diambil sebanyak 200 sampel, sesuai dengan kriterian penetapan jumlah sampel, bahwa untuk ilmu sosial jumlah sampel sebanya 100-500 orang adalah cukup (Sugiyono, 2010).

\section{Teknik Analisis}

Teknik analisis data yang digunakan dalam penelitian ini adalah multidimensional scaling (MDS). Penggunaan analisis Multidimensional scalling peneliti dapat mengetahui posisi persaingan (perceptual mapping) antara industri batik di Jawa Timur dengan pesaingnya yang mempunyai kemiripan dengannya (Santoso, 2002). 
HASIL DAN PEMBAHASAN

\section{Hasil Analisis Multidimensional Scalling (MDS)}

Sebelum dilakukan pemetaan terhadap 9 sentra batik Jawa Timur yaitu Bangkalan, Sidoarjo, Lamongan, Tuban, pasuruan, Tulungagung, Mojokerto, Ponorogo dan Banyuwangi, terlebih dahulu dilakukan uji validitas dan reliabilitas data MDS lebih dahulu. Uji validitas pada MDS mempunyai maksud untuk mengukur seberapa baik model MDS sesuai dengan input data atau dapat juga dianggap sebagai tolak ukur untuk mengetahui seberapa besar efektifitas model MDS dalam mengolah data input. Ukuran yang digunakan dalam validitas ini adalah nilai $\mathrm{R}$-square (indeks korelasi kuadrat).

Nilai R-square sebesar pada Sembilan atribut yang dipersepsikan konsuemn memiliki nilai lebih besar dari 0,6 maka dapat disimpulkan bahwa data layak diolah dengan MDS. Reliabilitas pada data MDS adalah untuk mengindikasikan kualitas penyelesaian MDS terhadap data input atau mengukur badness of fit (ketidakcocokan) dapat diketahui nilai Stress sebesar ada diantara kisaran 5$10 \%$. Menurut Malhorta (1996) nilai Stress ini dikategorikan fair (Baik) karena berada diantara nilai 5\% dan $10 \%$.
Persepsi konsumen berdasarkan atribut pada produk batik terdiri dari 9 atribut yang dinilai yaitu: (1) Kualaitas bahan kain, (2) kualitas oewarnaan, (3) harga, (4) corak/ motif, (5) ragam warna, (6) desain yang inovatif, (7) popularitas, (8) makna intrinsic dan (9) nilai seni, yang dapat dilihat pada konfigurasi perceptual mapping yang diperoleh pada Gambar terlihat bahwa perceptual mapping pada dua dimensi terdiri dari empat kuadran.

\section{Hasil Pemetaan (Perceptual Mapping)}

1. Kualitas bahan kain digunakan Peta posisi batik berdasarkan kualitas bahan kain yang digunakan untuk masing-masing daerah di Jawa Timur dari hasil pengolahan MDS dapat dilihat pada Gambar1, diketahui posisi batik Banyuwangi letaknya cukup jauh dengan delapan batik lain yang ada di Jawa Timur pada dimensi 1. Hal ini mempunyai arti bahwa terdapat perbedaan persepsi atas atribut kualitas bahan kain yang digunakan batik Banyuwangi dibandingkan pesaingpesaingnya. Batik Tuban, Pasuruan dan Tulungagung mempunyai posisi yang berdekatan mengenai atribut kualitas bahan kain yang digunakan. Sedangkan batik Bangkalan menunjukkan posisi paling berbeda (tidak mirip) dengan batik lainnya pada dimensi. Gambar 1 akan memberikan gambaran peta posisi dimaksud. 
2. Kualitas Pewarnaan Kain Digunakan Peta posisi batik berdasarkan kualitas pewarnaan kain yang digunakan untuk masing-masing daerah di Jawa Timur dari hasil pengolahan MDS dapat dilihat pada Gambar .2, diketahui posisi batik Banyuwangi letaknya cukup jauh dengan delapan batik lain yang ada di Jawa Timur pada dimensi 1. Hal ini mempunyai arti bahwa terdapat perbedaan persepsi atas atribut kualitas pewarnaan kain yang digunakan batik Banyuwangi dibandingkan pesaingpesaingnya. Sedangkan batik Tulungagung menunjukkan posisi paling berbeda (tidak mirip) dengan batik lainnya mengenai kualitas pewarnaan kain yang digunakan pada dimensi 2. Gambar 2 akan memberikan gambaran peta posisi dimaksud.

3. Corak/ Motif

Peta posisi batik berdasarkan Corak/ motif untuk masing-masing daerah di Jawa Timur dari hasil pengolahan MDS dapat dilihat pada Gambar 3, diketahui posisi batik Banyuwangi letaknya cukup jauh dengan delapan batik lain yang ada di Jawa Timur pada dimensi 1 . Hal ini mempunyai arti bahwa terdapat perbedaan persepsi atas atribut Corak/ motif batik Banyuwangi dibandingkan pesaing-pesaingnya. Batik Sidoarjo dan Bangkalan mempunyai posisi yang berdekatan mengenai atribut Corak/motif yang digunakan. Sedangkan batik Mojokerto menunjukkan posisi paling berbeda (tidak mirip) dengan batik lainnya mengenai Corak/motif pada dimensi 2 . Gambar 3 akan memberikan gambaran peta posisi dimaksud.

4. Ragam Warna Digunakan

Peta posisi batik berdasarkan Ragam warna yang digunakan untuk masingmasing daerah di Jawa Timur dari hasil pengolahan MDS dapat dilihat pada Gambar.4, diketahui posisi batik Banyuwangi letaknya cukup jauh dengan delapan batik lain yang ada di Jawa Timur pada dimensi 1. Hal ini mempunyai arti bahwa terdapat perbedaan persepsi atas atribut Ragam warna yang digunakan batik Banyuwangi dibandingkan pesaingpesaingnya. Batik Pasuruan, Tuban, Bangkalan dan Lamongan mempunyai posisi yang berdekatan mengenai atribut Ragam warna yang digunakan. Sedangkan batik Mojokerto menunjukkan posisi paling berbeda (tidak mirip) dengan batik lainnya mengenai Ragam warna yang digunakan pada dimensi 2. Gambar 4 akan memberikan gambaran peta posisi dimaksud. 
Derived Stimulus Configuration

Euclidean distance model

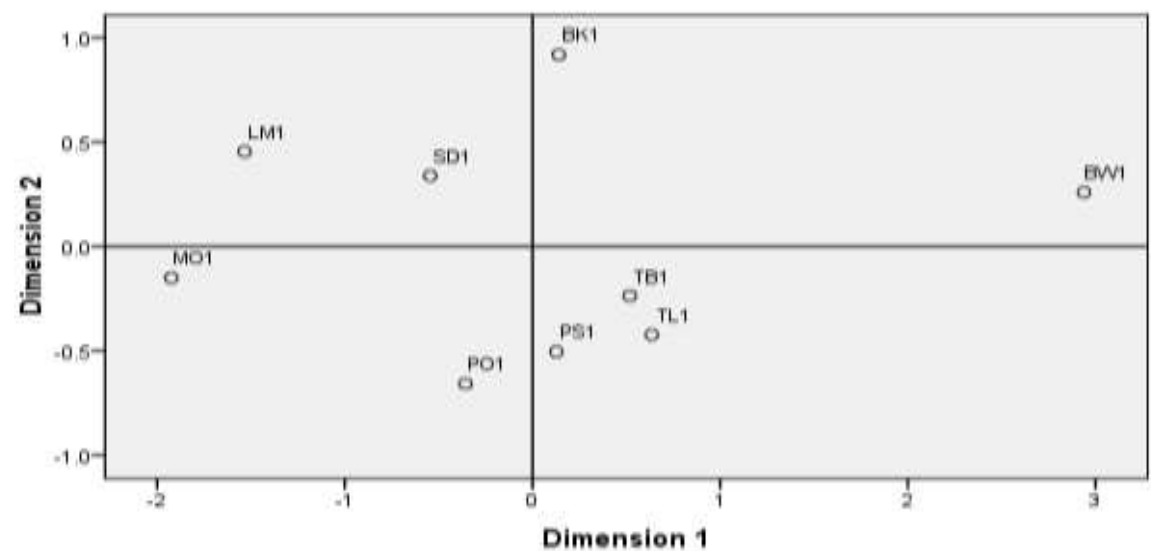

Sumber : Data Diolah (2020)

Gambar 1. Peta Posisi Batik Berdasarkan Kualitas Bahan Kain Digunakan

Derived Stimulus Configuration

Euclidean distance model

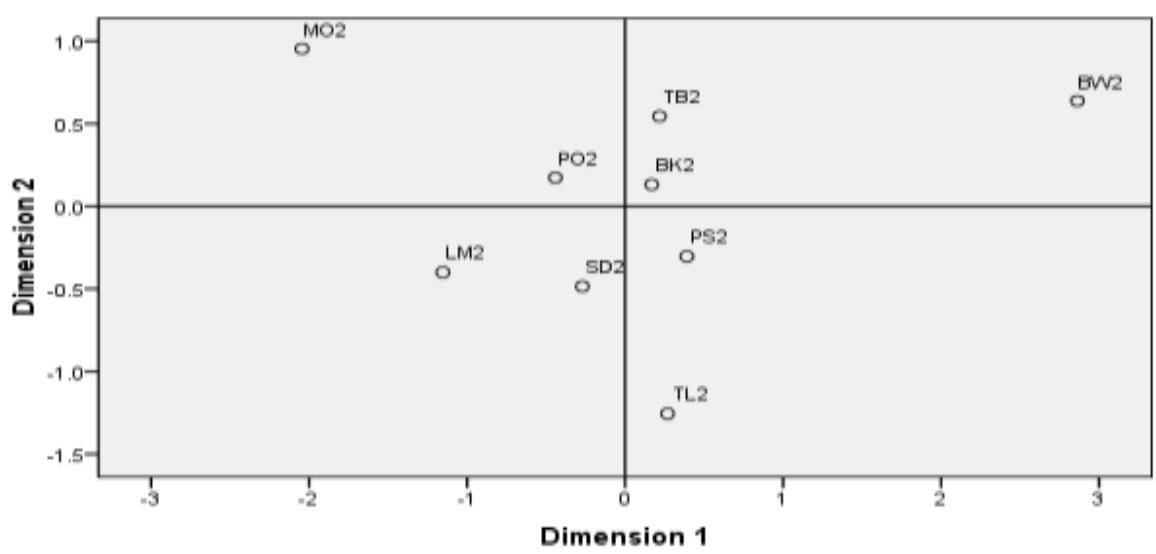

Sumber : Data Diolah (2020)

Gambar 2. Peta Posisi Batik Berdasarkan Kualitas Pewarnaan Kain Digunakan

Derived Stimulus Configuration

Euclidean distance model

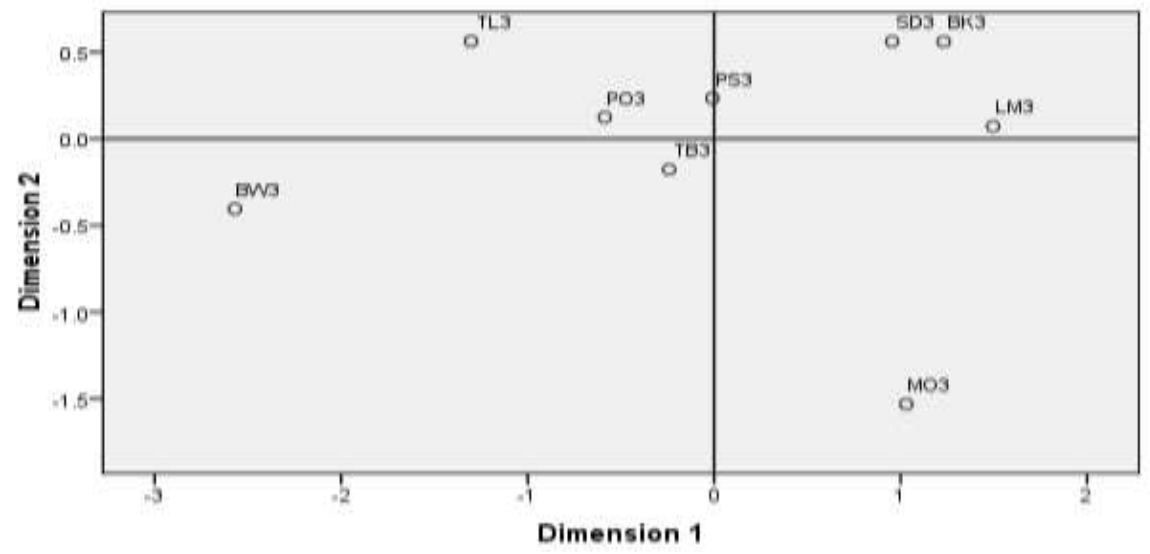

Sumber : Data Diolah (2020)

Gambar 3. Peta Posisi Batik Berdasarkan Corak/motif 


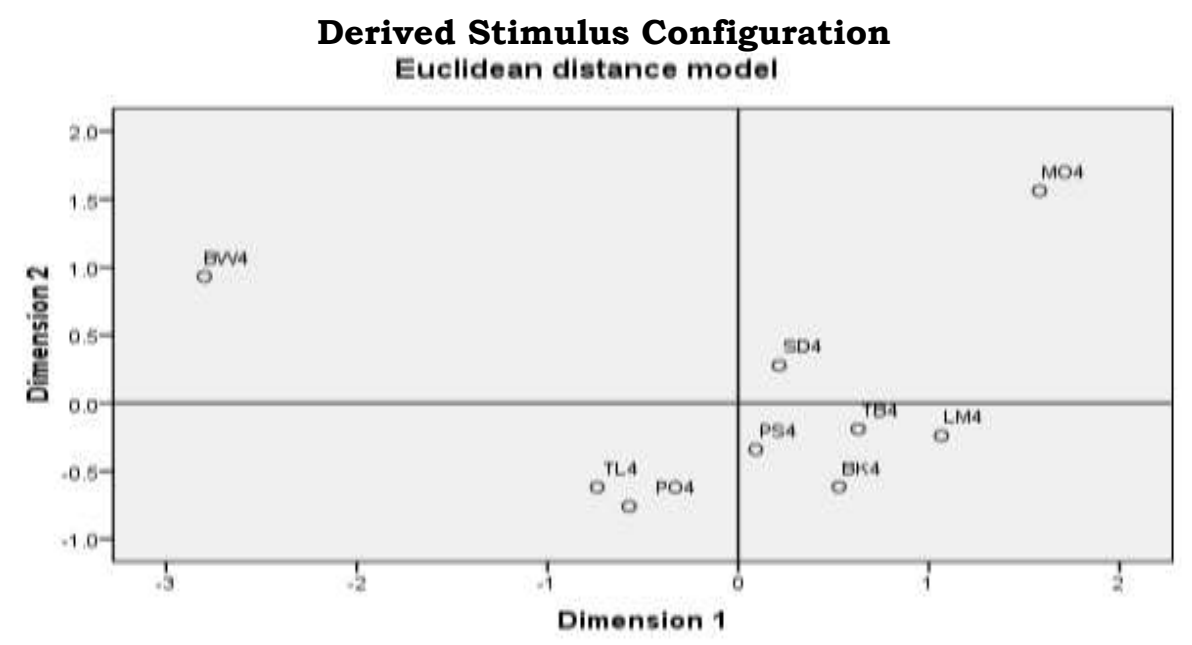

Sumber : Data Diolah (2020)

Gambar 4. Peta Posisi batik Berdasarkan Ragam Warna Digunakan

5. Harga

Peta posisi batik berdasarkan Harga untuk setiap daerah di Jawa Timur dari hasil pengolahan MDS dapat dilihat pada Gambar 5.5, diketahui posisi batik Banyuwangi letaknya cukup jauh dengan delapan batik lain yang ada di Jawa Timur pada dimensi 1. Hal ini memiliki arti bahwa terdapat perbedaan persepsi atas atribut Harga batik Banyuwangi dibandingkan pesaingnya. Sedangkan batik Sidoarjo menunjukkan posisi paling berbeda (tidak mirip) dengan batik lainnya mengenai Harga pada dimensi 2. Gambar 5 memberikan gambaran peta posisi dimaksud.

6. Inovasi desain

Peta posisi batik berdasarkan Inovasi desain untuk masing-masing daerah di Jawa Timur dari hasil pengolahan MDS dapat dilihat pada Gambar 6, diketahui posisi batik Banyuwangi letaknya cukup jauh dengan delapan batik lain yang ada di Jawa Timur pada dimensi 1 . Hal ini mempunyai arti bahwa terdapat perbedaan persepsi atas atribut Inovasi desain batik Banyuwangi dibandingkan pesaingnya. Batik Ponorogo dan Tuban memiliki posisi berdekatan mengenai atribut Inovasi desain. Sedangkan batik Mojokerto memiliki posisi paling berbeda (tidak mirip) dengan batik lainnya mengenai Inovasi desain pada dimensi 2. Gambar 6 memberikan gambaran peta posisi dimaksud.

7. Popularitas

Peta posisi batik berdasarkan Popularitas untuk masing-masing daerah di Jawa Timur dari hasil pengolahan MDS dapat dilihat pada Gambar 5.7, diketahui posisi batik Tulungagung letaknya cukup jauh dengan delapan batik lain yang ada di Jawa Timur pada dimensi 1. Hal ini 
memiliki arti bahwa terdapat perbedaan persepsi atas atribut Popularitas batik Tulungagung dibandingkan pesaingnya. Batik Ponorogo, Pasuruan dan Tuban mempunyai posisi yang berdekatan mengenai atribut Popularitas. Batik Sidoarjo menunjukkan posisi paling berbeda (tidak mirip) dengan batik lainnya mengenai Popularitas pada dimensi 2. Gambar 7 akan memberi gambaran peta posisi dimaksud.

8. Nilai seni

Peta posisi batik berdasarkan Nilai seni untuk masing-masing daerah di Jawa Timur dari hasil pengolahan MDS dapat dilihat pada Gambar 8, diketahui posisi batik Banyuwangi letaknya cukup jauh dengan delapan batik lain yang ada di Jawa Timur pada dimensi 1. Hal ini mempunyai arti bahwa terdapat perbedaan persepsi atas atribut Nilai seni batik Banyuwangi dibandingkan pesaing-pesaingnya. Batik Sidorajo dan Lamongan mempunyai posisi yang berdekatan mengenai atribut Nilai seni. Sedangkan batik Tulungagung menunjukkan posisi paling berbeda (tidak mirip) dengan batik lainnya mengenai Nilai seni pada dimensi 2 . Gambar 8 akan memberikan gambaran peta posisi dimaksud.

9. Makna intrinsik
Peta posisi batik berdasarkan Makna intrinsik untuk masing-masing daerah di Jawa Timur dari hasil pengolahan MDS dapat dilihat pada Gambar 9, diketahui posisi batik Banyuwangi dan Mojokerto letaknya cukup jauh dengan delapan batik lain yang ada di Jawa Timur pada dimensi 1. Hal ini mempunyai arti bahwa terdapat perbedaan persepsi atas atribut Makna intrinsik batik Banyuwangi dan Mojokerto dibanding pesaingnya. Batik Tulungagung menunjukkan posisi paling berbeda (tidak mirip) dengan batik lainnya mengenai Makna intrinsik pada dimensi 2. Gambar 9 memberikan gambaran peta posisi dimaksud.

Hasil Penelitian ini menunjukkan peta persaingan batik diantara pesaing industri batik yang sama di kota lain di Jawa Timur. Perceptual mapping yang dihasilkan dari analisis multidomensial scalling, menunjukkan posisi persaingan, siapa pesaing terdekat dari batik tersebut dari setiap atribut yang dinilai. Hal ini mendukung penelitian yang sama mengenai positioning produk dengan menggunakan multidimensional scalling dari Putri et al., (2018) yang mendeskripsikan posisi persaingan antara produk smartphone di Samarinda dan penelitian dari Syahputra (2014) mendeskripsikan posisi persaingan pada jasa travel di Bandung.

\section{Derived Stimulus Configuration}




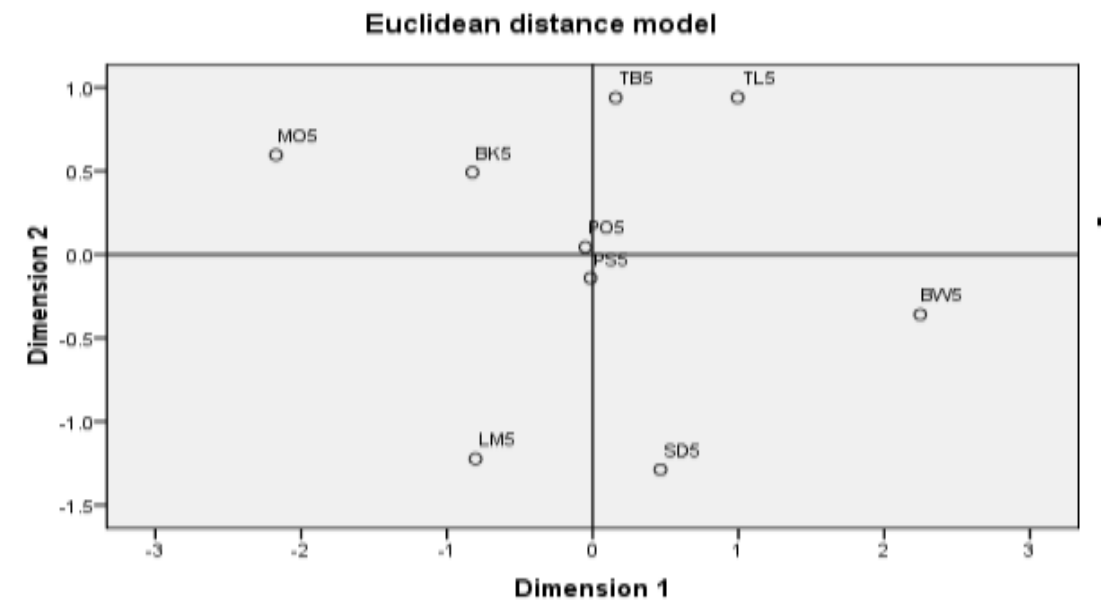

Sumber : Data Diolah (2020)

Gambar 5. Peta Posisi Batik Berdasarkan Harga

Derived Stimulus Configuration

Euclidean distance model

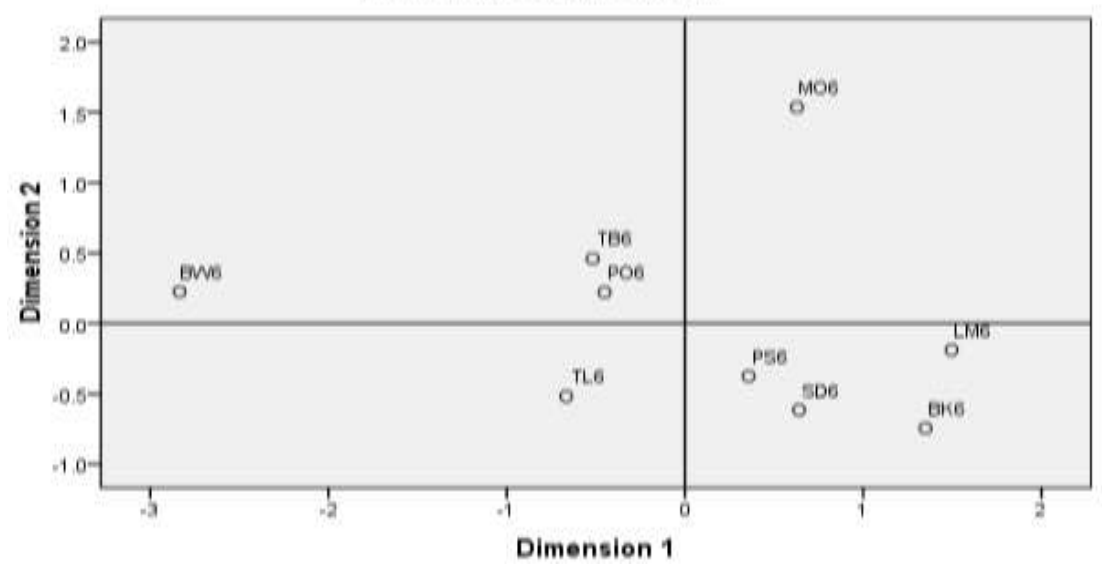

Sumber : Data Diolah (2020)

Gambar 6. Peta Posisi Batik Berdasarkan Inovasi desain

Derived Stimulus Configuration

Euclidean distance model

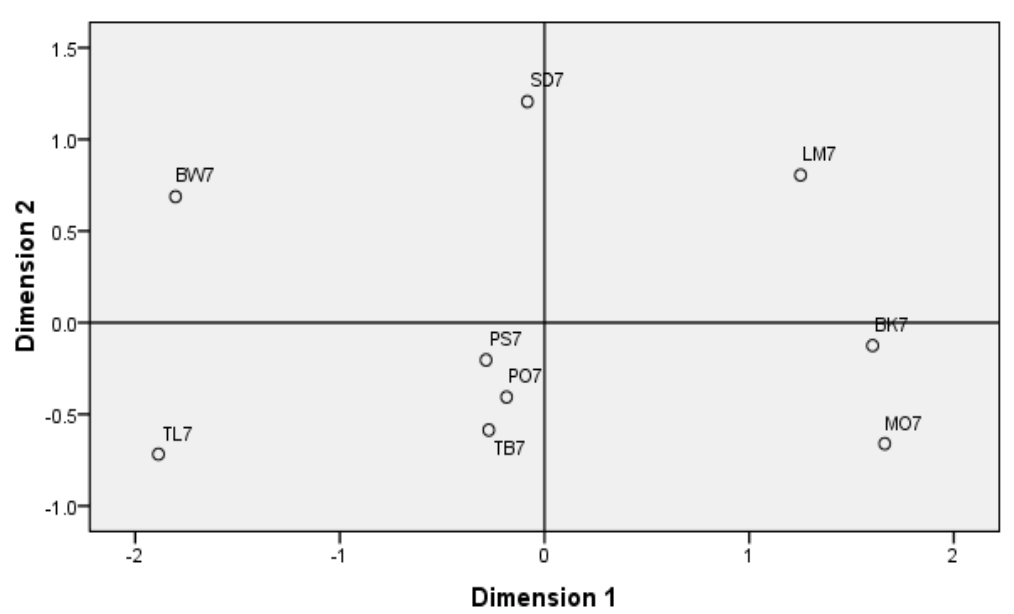

Sumber : Data Diolah (2020)

Gambar 7. Peta Posisi Batik Berdasarkan Popularitas 
Derived Stimulus Configuration

Euclidean distance model

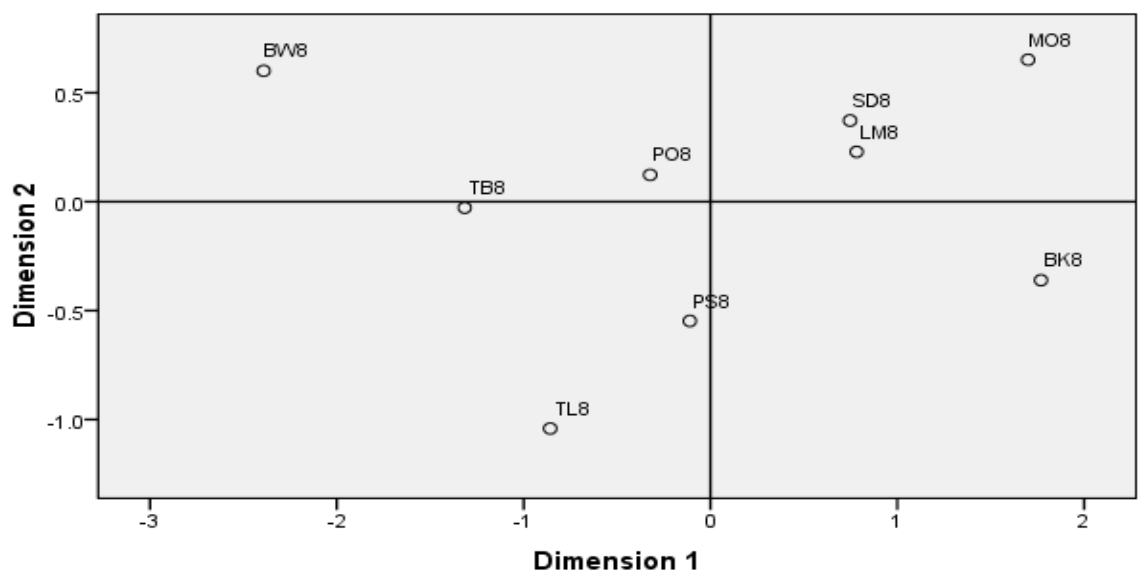

Sumber : Data Diolah (2020)

Gambar 8. Peta Posisi Batik Berdasarkan Nilai seni

Derived Stimulus Configuration

Euclidean distance model

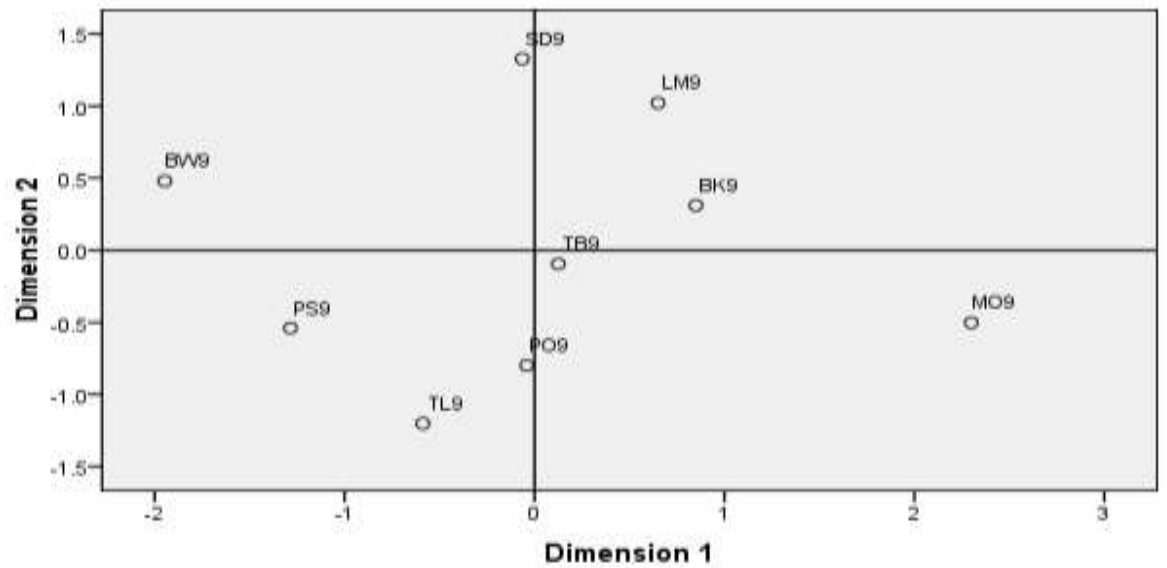

Sumber : Data Diolah (2020)

Gambar 9. Peta Posisi Batik Berdasarkan Makna intrinsik

\section{KESIMPULAN}

Terdapat perbedaan persepsi atas atribut kualitas bahan kain yang digunakan batik Banyuwangi dibandingkan pesaingpesaingnya. Batik Tuban, Pasuruan dan Tulungagung mempunyai posisi yang berdekatan mengenai atribut kualitas bahan kain yang digunakan. Sedangkan batik Bangkalan menunjukkan posisi paling berbeda (tidak mirip) dengan batik lainnya.
Terdapat perbedaan persepsi atas atribut kualitas pewarnaan kain yang digunakan batik Banyuwangi dibandingkan pesaing-pesaingnya. Sedangkan batik Tulungagung menunjukkan posisi paling berbeda (tidak mirip) dengan batik lainnya mengenai kualitas pewarnaan kain.

Terdapat perbedaan persepsi atas atribut Corak/motif batik Banyuwangi dibandingkan pesaing-pesaingnya. Batik 
Sidoarjo dan Bangkalan mempunyai posisi yang berdekatan mengenai atribut Corak/motif yang digunakan. Sedangkan batik Mojokerto menunjukkan posisi paling berbeda (tidak mirip) dengan batik lainnya mengenai Corak/motif.

Terdapat perbedaan persepsi atas atribut Ragam warna yang digunakan batik Banyuwangi dibandingkan pesaingpesaingnya. Batik Pasuruan, Tuban, Bangkalan dan Lamongan mempunyai posisi yang berdekatan mengenai atribut Ragam warna yang digunakan. Sedangkan batik Mojokerto menunjukkan posisi paling berbeda (tidak mirip) dengan batik lainnya mengenai Ragam warna.

Terdapat perbedaan persepsi atas atribut Harga batik Banyuwangi dibandingkan pesaing-pesaingnya. Sedangkan batik Sidoarjo menunjukkan posisi paling berbeda (tidak mirip) dengan batik lainnya mengenai Harga.

Terdapat perbedaan persepsi atas atribut Inovasi desain batik Banyuwangi dibandingkan pesaing-pesaingnya. Batik Ponorogo dan Tuban mempunyai posisi yang berdekatan mengenai atribut Inovasi desain. Sedangkan batik Mojokerto menunjukkan posisi paling berbeda (tidak mirip) dengan batik lainnya mengenai Inovasi desain.

Terdapat perbedaan persepsi atas atribut Popularitas batik Tulungagung dibandingkan pesaing-pesaingnya. Batik
Ponorogo, Pasuruan dan Tuban mempunyai posisi yang berdekatan mengenai atribut Popularitas. Sedangkan batik Sidoarjo menunjukkan posisi paling berbeda (tidak mirip) dengan batik lainnya mengenai Popularitas.

Terdapat perbedaan persepsi atas atribut Nilai seni batik Banyuwangi dibandingkan pesaing-pesaingnya. Batik Sidorajo dan Lamongan mempunyai posisi yang berdekatan mengenai atribut Nilai seni. Sedangkan batik Tulungagung menunjukkan posisi paling berbeda (tidak mirip) dengan batik lain mengenai Nilai seni.

Terdapat perbedaan persepsi atas atribut Makna intrinsik batik Banyuwangi dan Mojokerto dibandingkan pesaingpesaingnya. Sedangkan batik Tulungagung menunjukkan posisi paling berbeda (tidak mirip) dengan batik lainnya mengenai Makna intrinsik.

\section{IMPLIKASI DAN SARAN PENELITIAN}

Kontribusi penelitian ini disajikan dalam bentuk kontribusi teoritis dan konribusi praktis. Kontribusi teoritis yang dihasikan adalaha bahwa penelitian ini mendukung penelitian sebelumnya, bahwa pemasar bisa mengetahui posisi persaingan dalam industry melalui atribut yang dipersepsikan konsumen. Implkasi penelitian ini sangat berguna bagi pemasar untuk mengetahui siapa pesaing terdekatnya sehingga pemasar dapat menerapkan strategi yang 
tepat untuk menghadapai pesaing tersebut. Pengusaha/pengajin Batik sebaiknya membuat produk dengan nilai seni yang tinggi yang mencirikan budaya bangsa indonesia. Varian produk yang dibuat mengakomodasi segmen pasar para pekerja di sektor formal dan juga cocok untuk digunakan saat mereka mengikuti kegiatan sosial pada komunitas masing-masing.

Keterbatasan penelitian ini terletak pada pemilihan sampel, karena konsumen mengetahui atribut produk yang diketahuinya saja, pada penelitian selanjutnya pemilihan konsumen sebaiknya pada konsumen yang mengetahui semua karakteristik dari usaha yang dibandingkannya. Penelitan selanjutnya juga dapat meneliti mengenai kebijakan segmentasi, targeting dan positioning produk batik dalam memasarkan produknya di masyarakat.

\section{ACKNOWLEDGEMENT}

Ucapan Terima kasih dari Tim Peneliti dihaturkan kepada DP2M Dikti sebagai pemberi dana penelitian ini, dan pimpinan Universitas Wijaya Kusuma Surabaya beserta jajarannya yang telah mengizinkan kami turut berpartisipasi dalam Hibah Penelitian Strategi Nasional. Kami juga mengucapkan terimakasih kepada pemilik IKM Batik Di Jawa Timur yang telah menyediakan waktu dan tempat untuk dilakukannya penelitian ini.

\section{DAFTAR PUSTAKA}

Alhusain, Achmad Sani. (2015). Kendala Dan Upaya Pengembangan Industri Batik Di Surakarta Menuju Standardisasi (Efforts and Obstacles in the Development of Batik Industry in Surakartatowards Standardization); P3DI Bidang Ekonomi dan Kebijakan Publik; Setjen DPR RI.

Ariem Tsuluts, Saiful Mukmin, Agus Suryono, dan Abdullah Said. 2010. Implementasi Rencana Strategi Pemerintah dalam Pengembangan Usaha Batik Tulis Tenun Gedog (Studi di Dinas Perekonomian dan Pariwisata Kabupaten Tubandan di Usaha Batik Tulis Tenun Gedog di DesaKedungrejo Kecamatan Kerek Kabupaten Tuban). Vol. 1, No. 6, Hal.1131-1140

Doyle, P., \& Saunders, J. (1985). Market segmentation and positioning in specialized industrial markets. Journal of marketing, 49(2), 24-32.

Johannes, j., and erida, e. (2018). Strategi Positioning Batik Jambi Melalui Atribut Produk. Digest Marketing, 3(2), 62-73

Kotler, P. \& Keller, K., \& (2007). Manajemen Pemasaran edisi 12 jilid 1. Jakarta: PT. Indeks.

Kotler, Philip dan Gary Armstrong (2008). Prinsip -prinsip Pemasaran. Edisi 12. Jilid 1. Jakarta: Erlangga.

Kotler, P., \& Keller, K. L. (2008). Manajemen Pemasaran (Edisi Kedua Belas), Cetakan Ketiga. Jakarta: PT. Indeks. 
Moschis, G. P., Lee, E., \& Mathur, A. (1997). Targeting the mature market: opportunities and challenges. Journal of consumer marketing.

Oentoro, Deliyanti. (2012). Manajemen Pemasaran Modern. Yogyakarta: Laks Bang

PressIndo.

Putri, D. S., Wahyuningsih, S., \& Goejantoro, R. (2018). Analisis Positioning dengan Menggunakan Multidimensional Scaling Nonmetrik. JURNAL EKSPONENSIAL, 9(1), 85-94.

Santoso, Singgih.2002. Mengolah Data Statistik Secara Professional, Elex Media Komputindo, Jakarta

Sugiyono, S. (2010). Metode penelitian kuantitatif dan kualitatif dan R\&D.

Swastha, Basu dan Irawan. 2004. Manajemen Pemasaran Modern. Surabaya : Liberty.

Syahputra, B. (2014). Analisis Positioning Jasa Transportasi Travel Bandung-Jakarta PP Berdasarkan Persepsi Pelanggan di Kota Bandung. Jurnal Manajemen Indonesia, 14(2), 128-139.

Tjiptono, F. (2008). Strategi Pemasaran Edisi 3. Yogyakarta: Andi.

Zakaria, R., Fahma, F., \& Astuti, E. R. (2005). Perencanaan Strategi Pemasaran (Segmentation, Targetting dan Positioning) Koran Harian Solopos Berdasarkan Persepsi Konsumen. Performa: Media Ilmiah Teknik Industri, 4(1). 